\title{
US-Kenya Economic Relations under Obama and Their Image in the Kenyan News Discourse
}

\section{Vilém Řehák}

\section{Charles University}

\begin{abstract}
Economic cooperation between the US and Kenya has reflected the ups and downs in the relations between the two countries. Since independence, both countries have converged on security issues and diverged on questions of democracy and human rights. When Barack Obama was elected as the President of the US, Kenya expected to get an "Obama bonus" in the form of closer trade and investment cooperation. This article analyzes what is the image of USKenya economic relations in the news discourse. The analysis reveals that three different and competing narratives are present in the news discourse in Kenya. The US disseminates a narrative that economy, security, good governance and human resources are four interconnected and mutually reinforcing pillars of African development; Kenya must make progress in all these four pillars, and the US is ready to help Kenya. Kenyan leaders seem to internalize the economic part of the narrative and accept the nexus between economy and security, but they reject the nexus between economy and political issues. Finally, the Kenyan society internalizes both these narratives, albeit to a different degree, with the latter prevailing over the former. However, it also produces its own narrative, which presents current US-Kenya economic relations in a different perspective. The whole US engagement in Kenya hardly goes beyond the symbolical level. It is driven by US economic interests and competition with China, while there is no "Obama bonus" for Kenya.
\end{abstract}

\section{Keywords}

Kenya-US economic relations; strategic narratives; soft power; news discourse; media discourse analysis

\section{Introduction}

Election of Barack Obama as the president of the US caused "pure excitement throughout the African continent" (Ilo 2015, 289), particularly in Kenya, his father's homeland. Shortly after being elected, he outlined four pillars of his Africa policy: democracy and good governance, economic opportunity,

\footnotetext{
*Vilém Řehák, Department of International Relations, Institute of Political Sciences, Faculty of Social Sciences, Charles University, U Kř́íže 8, 15800 Prague, Czech Republic; vilem.rehak@seznam.cz. The author gratefully acknowledges the research assistance of Dr. Adéla Brožová.

This study was supported by the Charles University in Prague, project "Trade regimes in sub-Saharan Africa” under GAUK No. 834214.
} 
public health and the peaceful resolution of conflicts (Obama 2009). In June 2012, he further elaborated these pillars in the new "U.S. Strategy toward Sub-Saharan Africa."

In the economic domain, Obama stated that America could "do more": open doors to goods and services from Africa, promote investment into infrastructure and train entrepreneurs to enhance local business capacities (Obama 2009). The 2012 strategy aimed to "boost broad-based and inclusive economic growth, including through trade and investment" so as Africa can be "the world's next major economic success story". To achieve this goal, five actions were outlined as crucial: to encourage legal, regulatory and institutional reforms in order to promote an enabling environment for trade and investment; to improve economic governance; to promote regional integration and improve regional infrastructure; to expand African capacity to effectively access and benefit from global markets by extending preferential US trade regime toward Africa and increasing technical assistance and to encourage US companies to trade with and invest in Africa (White House 2012).

This article focuses on the image of Obama's foreign economic policy in the Kenyan news discourse as represented by the leading local newspaper The Daily Nation. The analysis seeks to identify which narrative(s) about USKenya economic relations circulates in the local news discourse and who disseminates them. This analysis is by no means a complex analysis of how the presidency of Obama is perceived in Kenya. However, even with this partial scope, the analysis can reveal some important aspects of the perceptual dimension of US-African relations, which is an inseparable part of the soft power of the US on the continent.

The article proceeds as follows. First, the perceptual dimension of international relations within the theoretical framework of soft power and strategic narratives and within the methodological framework of news discourse analysis is discussed. Second, a brief introduction to the history of US-Kenya economic relations is discussed. Third, expectations and results of the presidency of Obama on US-Kenya relations are presented. Finally, news discourse of the The Daily Nation with the aim to identify different narratives on the US-Kenya economic cooperation and their bearers is analyzed.

\section{Soft power, strategic narratives and the news discourse}

Joseph Nye distinguished between three sources of power. Military power and economic power represent the "classic" hard power based on coercion (force, sanctions) and inducements (payments, bribes). Soft power is a "modern" form of power based on agenda setting (institutions, diplomacy) 
and attraction (values, culture, ideas). Although soft power is increasingly important in the globalized and interconnected world, it does not replace hard power but rather complements it. World politics is "a three-dimensional chess game in which one can win only by playing vertically as well as horizontally" (Nye 2004, 4). Each of these "chessboards" is relevant in different degrees in different relationships (Nye 2004, 30). Smart power is neither hard nor soft; it is both (Nye 2004, xiii).

Unlike hard power, soft power is a two-way relationship. It depends not only on intentions and actions of the projecting country but also on acceptance by the receiving audiences. The projecting country must frame its objectives into a coherent story, which will be persuasive for the intended or potential audience, at least more persuasive than the stories of other countries. Contemporary politics is about "whose story wins" (Nye 2004, 106).

Soft power is to a large extent communication power. This communicative dimension of international relations is captured by the theory of strategic narratives. This theory takes into account the formation of narratives within the projecting country, the projection of narratives from the projecting country to the receiving country and the reception of narratives in the receiving country (Miskimmon et al. 2012, 6-7). Strategic narratives are "future oriented identity claims that articulate a distinctive (national/regional) position on a specific issue or policy domain" (Miskimmon et al. 2012, 4), including global economic relations. Their power effect is domestically constitutive (creating identity) and internationally behavioral (shaping behavior). They are a communicative tool for political elites. Their aims are:

- to construct a shared meaning to the past, present and future of international politics;

- to articulate state's interests, values and aspirations for the international order;

- to articulate end states and ways how to achieve them;

- to manage expectations about behavior in the international system;

- to change the discursive environment;

- to shape the behavior of domestic and international actors and

- to extend own influence (Miskimmon et al. 2012, 3-4; Miskimmon et al. 2013, 2-4).

Strategic narratives go beyond the state-centric level and focus also on different non-state actors such as interest groups, private sector, NGOs, universities, churches and media. 
Media news is naturally occurring and widely disseminated text appearing in the normal day-to-day activities (Phillips - Hardy 2002, 71). It is also a very important tool for public diplomacy, through which narratives can be projected. However, media news is not only a tool for the dissemination of narratives but also an actor of its own. Mainstream news editors and journalists are important gatekeepers. They can reproduce a strategic narrative, keep it out or authoritatively reinterpret it for audiences (Miskimmon et al. 2013, 157). In this respect, (mainstream) media are not neutral or rational mediators, but part of the political, social and economic status quo. They (in)directly presuppose some positions or opinions and help to reproduce preformulated ideologies (van Dijk 1988, 179).

However, media are important sites not only for the reproduction but also for the contestation of official discourses (Weldes 2006, 182). Naturally, not all voices appear in the media, and those that do appear are not expressed on equal terms (Phillips - Hardy 2002, 85); this is partly dependent upon the level of press freedom in any given country and upon the level of independence of any given media. Moreover, readers rarely create their knowledge solely from media news. Rather, they compare it with their previous knowledge within the framework of prevailing collective ideologies.

Thus, news discourse serves as a filter between preformulated ideas of elites and everyday stories of people (van Dijk, cited in Wodak 1996, 109). It is a frame through which the social world is constructed (van Dijk 1988, vii, 8). News reports "are the main form of public discourse that provides the general outline of social, political, cultural, and economic models of social events, as well as the pervasively dominant knowledge and attitude structures that make such models intelligible" (van Dijk 1988, 182).

Analyzing local media is thus one of the possible and promising directions for a research of strategic narratives and their projection and reception. Such an analysis can reveal which narratives circulate within the public space, who is advocating them and whether and how these narratives clash and affect each other.

To tackle with these questions, interpretive textual content analysis will be used. It is a formalized method to analyze the content of written texts in an interpretative way. It uses a fixed set of categories that guide data collection from documents and enable sorting and comparing the data. It analyzes the text itself while setting it to the wider societal context and to the relation with other texts. It analyzes what preceded the text or what the text reacts to, what is actually happening, what are the likely consequences of the current events or what people expect to happen, what are reactions to the current events and 
how do people evaluate the current events; it takes into account who is quoted in the text and who is an authoritative source of information. Such a method is well designed to analyze the news discourse as it can be used for a relatively large collection of texts, even for hundreds of articles.

\section{Brief History of the US-Kenya Economic Relations Containing the Soviet Union}

Historically, Africa was considered to be a European sphere of influence (Ilo $2015,283)$. The US refrained from forging a strong relationship with the continent until decolonization created both trade opportunities and political dangers. For Eisenhower and Kennedy, economic cooperation was a means of attracting African leaders into the Western camp. Economic relations between the US and Kenya were established before the latter's independence (Moegi 1993, 57, 87) and strengthened in the following decade as Kenya followed a free-market approach and had a high rate of economic growth.

However, the US engagement remained limited, because it had no direct strategic or economic interests in Africa (Lawson 2007, 1). Foreign policy under Johnson, Nixon and Ford focused on the competition with the Soviet Union. Africa was just "an adjunct of the West/East struggle" (Waters 2009, li) with the only aim to contain the Soviet influence on the continent (Banjo 2010, 140-141). The US-Africa policy was reactive, not proactive (Ilo 2015, 284). The US sent economic and military assistance to key allies and anticommunist rebel organizations with the aim to create a system of friendly regional powers and to undermine the Soviet client states (Waters 2009, lx).

Kenya was the only anti-communist country in East Africa and became a strategic US partner. This partnership culminated in 1980, when the two countries signed a military agreement that enabled the US to utilize facilities in Kenya and helped Kenya to deter the Somalian leader Siad Barre from attacking its territory. Paradoxically, agreement was signed under the presidency of Carter, who wished to overcome the Cold War logic and introduce to US-Africa policy new issues such as development, human rights and majority rule in Southern Africa. The revolution in Iran and the Soviet invasion to Afghanistan changed the international environment and pushed Carter toward accepting the Cold War logic (Waters 2009, lxii-lxiv).

Reagan continued with this hardline realism and aimed to defeat the Soviet Union. Kenya remained one of the key allies in Africa. The US channeled financial assistance to Kenya in order to maintain politico-economic and national security co-operation. By 1990, Kenya became the largest recipient of US aid in Africa (Maina 2005, 27) and the US became the second-largest 
foreign investor in Kenya (Moegi 1993, 51). This strategic partnership was not affected by ideological or political conflicts (Moegi 1993, 222), and the US did not challenge the rising authoritarianism of the Moi regime in the 1980s.

\section{Promoting Democracy and Human Rights}

With the end of the Cold War, Bush sought to define a new Africa policy reflecting the US position as the sole global leader and emphasizing its core values: peace, democracy, human rights, development and market economy. Bush ceased to support long-term allies with authoritarian regimes and pressed them to democratize (Waters 2009, lxvi).

The US started to criticize democratic deficiencies in Kenya after the rigged general elections in March 1988 (Moegi 1993, 188). When the police violently ended the opposition meeting in July 1990, the US Congress proposed the suspension of US aid to Kenya. Between 1989 and 1991, aid dropped by almost two-thirds (Moegi 1993, 111). Nevertheless, the realist logic was not fully over. Despite widespread criticism, the Kenyan government received more than 160 million USD in debt forgiveness from the US as a reward for its support and cooperation during the Gulf War (Moegi 1993, 97). Thus, "the Bush Administration cannot be attributed to have had a consistent voice calling for democratic reforms [and] human rights improvements in Kenya" (Maina 2005, 28). However, delays with the constitutional reforms, arbitrary arrests of opposition leaders and violations of human rights eventually led to suspending aid to Kenya in November 1991 (Mezzell 2010, 80). Only one month later, Moi reluctantly agreed to end one-party rule.

Under Clinton, the Africa policy was initially ad hoc, inconsistent and driven by domestic concerns rather than a vision (Waters 2009, lxvii). He followed the sentiment of US public that foreign policy had lost its importance and prioritized domestic issues. After the debacle in Somalia, he halted military aid to Africa, passed the strict legal conditions on the US participation in peacekeeping missions and passed budgetary cuts to foreign aid (Hesse 2005, 327-329). Support for the democratization of Africa also dampened, and the US foreign policy prioritized stabilization over political liberalization (Lawson 2007, 3).

\section{Promoting Trade and Investment}

Reactionary approach during the first term was replaced by an opportunistic approach during the second term (Hesse 2005, 338). For Clinton, free markets, democracy and human rights were seen as "intimately interwoven," and his foreign policy aimed to "increase the size and scope of the zone of 
market democracies". However, calls for a promotion of human rights were secondary and followed "only when and where it complemented (...) the economic imperatives of America's foreign policy" (Holland 2016, 5). Africa was acknowledged as a major emerging market with a wealth of resources and the only continent for which the US had no trade policy (Hesse 2005, 331). In 2000, the Congress approved the African Growth and Opportunity Act (AGOA) offering trade preferences to African exporters. However, access to the US market was conditioned by economic reforms and adherence to market-based economy and free trade (Hesse 2005, 332-333), which were seen as a right mechanism for development and democratization (Banjo 2010, 143).

The Africa policy under Clinton was based on "development through trade" approach (Banjo 2010, 140). It aimed to increase trade, while foreign aid was at historic lows (Ilo 2015, 286). This "words rather than resources" approach (Hesse 2005, 330) confirmed that Africa continued to have a "low priority status" for the US (Mezzell 2010, 83).

US-Kenyan relations entered the "business as usual" mode and focused on trade and investment (Maina 2005, 67; Mabera 2016, 371). However, the US still recognized the defining features of the Kenyan political-economic system: poor governance and low accountability of the government, high levels of corruption, the lack of progress on reforms, inadequate infrastructure, insecurity and the low level of human rights record. Both the International Monetary Fund and the World Bank suspended new programs after the 1997 elections (Machar 2015, 196). Similarly, when President Clinton visited Africa in 1998 to meet with "a new generation of African leaders" (Waters 2009, lxviii), Kenya was by-passed. Hostile business environment in the country also discouraged US investors.

\section{Waging the War on Terror}

After September 11, 2001, George W Bush integrated security, economic development and political US interests in Africa into the broader framework of the War on Terror. It contained different measures capable to eradicate poverty, to improve the quality of life and to decrease the prevalence of extremism and terrorism on the continent (Hesse 2005, 334-335). He was a strong proponent of free markets, but he complemented trade and investment agenda with generous aid packages (Waters 2009, lxx). He rewarded economic freedom and neoliberal reforms with aid under the Millennium Challenge Account, focusing on agriculture, energy sector and infrastructure (White 2010, 8; Agyeman-Duah 2015, 38). He directed an unprecedented amount of 
money to combat the HIV/AIDS pandemic and malaria. He also supported education and signed into debt relief initiatives for developing countries.

In 2003, Kenya refused to endorse the invasion of Iraq without a UN mandate, opposed the establishment of US military base in the country, disapproved the Suppression of Terrorism Act and refused to sign agreement with the US on impunity of its citizens. The US declared Kenya an unsafe country and advised its citizens not to travel there (Maina 2005, 57-59). However, common security interests helped to overcome these tensions. Kenya recognized "the need for a pragmatic foreign policy that is sensitive to the geopolitical and economic dimensions of opportunistic security threats, such as piracy and terrorism" (Mabera 2016, 372). The US needed Kenya as an anchor country in the global war on terror. In 2008, Kenya became once again the leading African recipient of US foreign aid (Ilo 2015, 288).

Paradoxically, as Bush "has made African development and eradication of disease important albeit secondary foreign policy goals, (...) by the end of his presidency many commentators were calling his Africa policy the most positive aspect of his foreign policy legacy" (Waters 2009, 1). However, "rhetoric about the role of Africa in the war on terrorism has amounted to very little actual change in the U.S. approach to Africa" (Lawson 2007, 9). Africa has remained marginal, and the US did not have a clear Africa policy (Agyeman-Duah 2015, 34).

\section{Expectations and Results of the Obama Presidency}

This brief summary shows that close partnership stemmed from shared security interests and was reflected in high levels of US aid to Kenya. On the other side, the US was much less important partner in investment and trade. Moreover, President Mwai Kibaki focused his economic diplomacy on China and other Asian countries under the so-called "Look East policy" (Mabera 2016, 378). In 2008, Prime Minister Raila Odinga expressed his faith that Obama's election as the president of the US would lead to the expansion of relationships in terms of trade, direct investments and the influx of US tourists. Although close security cooperation was expected to continue, the main "Obama bonus" was seen in the economic domain and a greater prosperity for Kenya (Mathenge et al. 2008).

Munyi $(2018,51-53)$ differentiated four periods in US-Kenyan relations under Obama. In the first period, mutual relations became less cordial (Machar 2015, 189). There were big disagreements on democracy, fight against corruption, tribalism and justice. Obama and his Secretary of State Hillary Clinton pressed for constitutional reforms (Dumbuya 2015, 12). 
Economic relations stagnated, although it is not clear whether due to political tension or US economic situation amid the financial crisis. In mid-2011, the US ceased to criticize governance in Kenya and mutual relations entered the second period of "benign silence from both sides", reflecting the fact that both countries headed for the elections (Munyi 2018, 51).

The third period started in 2013 when relations worsened due to the International Criminal Court (ICC) issue. In its final report, the governmentsponsored Commission of Inquiry on Post-Election Violence identified the perpetrators and financiers of the violence. When the government refused to establish a special tribunal to try suspects, the six most responsible individuals were referred to the ICC (Mabera 2016, 368). Two of them, Uhuru Kenyatta and William Ruto, announced their intention to run in the 2013 elections for presidency and vice-presidency respectively. The British High Commissioner to Kenya Christian Turner announced that Britain would avoid regular contact with individuals charged by the ICC, meaning that Kenyan leaders would face travel bans and asset freezes if elected (Pflanz 2013). While Obama called for peaceful election reflecting the will of the people, without endorsing any of the candidates, Assistant Secretary of State for African Affairs Johnnie Carson warned that "people should be thoughtful about the impact that their choices have on their nation" and that these "choices have consequences" (Joselow 2013), causing a diplomatic discord.

In his inaugural speech, Kenyatta delineated four directions of his foreign policy: pan-Africanism, regionalism, Kenyan nationalism and multilateralism. His political rhetoric was directed against western governments, but the onslaught on the "imperialist West" and the adherence to pan-Africanism aimed to counteract the negative publicity associated with the ongoing ICC trials (Obala 2014, 6-8). US-Kenyan relations were "suspicious, tentative and tepid" (Munyi 2018, 52) and marked by harsh rhetoric from both sides, but in reality, there was no radical break between the two countries (Mabera 2016, 373).

In 2014, relations started to improve as both leaders put aside the political questions and focused on economic and security cooperation. ${ }^{1}$ In the economic domain, some results were visible. Exports from Kenya to the US under Obama had increased gradually and more than doubled. However, this rise had copied the general trend of rising Kenyan exports, while the territorial structure of export has not substantially changed. The US share on Kenyan exports oscillated between $5.5 \%$ and $7.5 \%$ throughout the period. Positive trend was much less clear for US exports to Kenya. Between 2008

1 Charges against Uhuru Kenyatta were finally dropped in December 2014. 
and 2013, exports increased by half. In 2014, exports increased almost three times. In 2015, exports decreased by more than a third. In 2016, exports further decreased by almost two-thirds. In relative terms, the US share on Kenyan imports moved from $3.5 \%$ in 2008 to $10.5 \%$ in 2014 and then back to $3.5 \%$ in $2016 .{ }^{2}$ From these figures it is unclear whether the upswing of US exports was only temporary, but it seems that the volatility of US exports to Kenya remains high.

The flow of US investment to Kenya started to rise in 2011 and peaked in 2014. Then, it fell down, but remained above the initial level. In 2016, the overall US stock was the second highest behind India, surmounting the British or Chinese stock (Munyi 2018, 59). This is a result of the Power Africa Initiative, which Obama announced in 2013 with the aim to mobilize private funding for investment in energy and electricity production. The US government committed 7 billion USD for Kenya, and private US companies added 4 billion USD through project funding (Munyi 2018, 58). Kenya also continued to be one of the biggest African beneficiaries of the US military aid under the new Security Governance Initiative. Finally, all the necessary steps to start the operation of direct flights were undertaken. ${ }^{3}$

\section{Narratives on the US-Kenya Economic Relations}

This article focuses on US-Kenyan economic relations and covers the period between January 2012 and September 2015. It is part of a wider research focusing on the image of Kenya's external economic relations in the local news discourse. The 2012/2015 period covers several milestones related to Kenya's economic relations with the US, the EU and China and within the East Africa Community (EAC), providing a researcher with a comprehensive collection of source data. ${ }^{4}$ This time framework fits well on the topic of this article as it includes the adoption of a new African strategy (June 2012), the announcement of the Power Africa initiative (June 2013), shift in the USKenyan relations toward the economic agenda (2014), first US-Africa Leaders

2 Own calculations based on data from www.trademap.org, Statistical Abstracts (Kenya National Bureau of Statistics, editions 2008, 2009, 2016, 2017) and Munyi (2018, 54).

3 Direct flights between Nairobi and New York are supposed to further boost trade and tourism. These flights will be operated by the Kenya Airways, starting in October 2018.

4 The end of the period is given by the time when I was studying the archived newspapers in the McMillan Memorial Library in Nairobi. Start of the period was chosen deliberately following the three basic criteria: (1) to include the most recent events related to the external economic relations of Kenya with the US, the EU and China and on the regional level; (2) to create a robust collection of articles allowing a researcher to analyze the existing narratives of the elites (both Kenyan and foreign elites) and reactions to these narratives in the local news discourse; (3) to limit the collection of articles so as the research remains feasible by one researcher in a reasonable time frame. The whole research was based on 586 articles, of which 78 dealt with the US-Kenyan economic relations. 
Summit in Washington (August 2014), extension of the AGOA preferential trade regime (June 2015) and Obama's visit to Kenya (July 2015).

\section{Media Environment in Kenya}

Source data for the analysis are the articles from the leading Kenyan newspaper The Daily Nation. Although this research relies on a single source of data, which poses a certain limitation, the chosen newspaper is an independent widely read newspaper operating within free media environment. It is likely to offer space for different voices, including the non-official ones. Analysis of media coverage of the 2007 election campaign and election violence shows that beyond their initial role of informing, main newspapers also provided a forum for a broad political debate (Rambaud 2008, 88). The Daily Nation is a reliable source of data as it is a very representative example of the Kenyan news discourse - although it is by no means a discourse representing the whole public arena in the country.

In 2002, media were granted full freedom of expression (Rambaud 2008, 5960). Press freedom is guaranteed by the 2010 Constitution, which prohibits the state from interfering with the editorial independence of media outlets. Local private media provide rigorous and critical coverage of politics and a diversity of views (Reporters without Borders 2017; Freedom House 2016). Media in Kenya are "vibrant, critically engaged and balanced" (Cheeseman 2014).

Newspapers remain the most important source of information for a significant part of Kenyan adult population. Obviously, there is a great urban/rural divide and $60 \%$ of rural people assert that they have never read a newspaper (Cheeseman 2014). For those people, the most popular news source is radio, particularly number of stations broadcasting in vernacular languages. However, these radio stations are geographically and culturally limited and do not represent a broad societal discourse.

The Daily Nation is the most important Kenyan newspaper, which is read by up to $20 \%$ of population over 15 years. ${ }^{5}$ It has the strongest position even among the youth to 24 years (GeoPoll 2015). Readership of The Daily Nation

5 Different sources estimate the number of copies sold every day between 170,000 and 200,000, with the Sunday edition reaching up to 250,000. However, the number of readers is much higher. As Rothmyer (2010) asserts, each newspaper in Kenya is typically read by fourteen people. GeoPoll survey (2015) indicates that the average readership of The Daily Nation is 4,379,400 per day, which is a $40 \%$ share of the national printed media market. Survey conducted by Afrobarometer (cited in Cheeseman 2014) revealed that while ten percent of adult Kenyans read a newspaper every day, almost half of the adult population read a newspaper at least once a week. This is confirmed by another analysis that states that the combined daily and weekly readership of The Daily Nation is 5,518,800 (Nyabuga Booker 2013, 20). 
is also regionally diffused with the strongest position in Central Province and Nairobi (Rambaud 2008, 79). Moreover, articles from The Daily Nation are published also on its website, which is among the ten most visited websites in Kenya (Nyabuga - Booker 2013, 21).

The Daily Nation is an independent newspaper published by the Nation Media Group (NMG). NMG is a private company founded in 1959 by the British business magnate, philanthropist and religious leader Aga Khan IV. NMG is listed on the Nairobi Stock Exchange with $45 \%$ of shares owned by the Aga Khan Fund for Economic Development.

NMG's editorial policy stresses independence from vested interests or external influences, responsibility for allowing different views to be expressed and focus on the objective and generally constructive criticism offered in the interests of the public at large. ${ }^{6}$ Empirical analysis shows that during electoral campaign in 2007, "the main media houses made a concerted effort to promote responsible journalism" and to achieve "quantitative impartiality" with a balanced coverage between the three main candidates (Rambaud 2008, 57-58, 77). This confirms that journalism of The Daily Nation complies with the NMG editorial policy.

\section{US Narrative}

The US narrative on the principles of its cooperation with Africa can be best derived from the quotations and writings of key US representatives. In August 2012, Secretary of State Hillary Clinton visited nine African countries, including Kenya.

Currently, US Secretary of State Hillary Clinton is on an 11-day tour of the continent to raise interest in security, sustainable partnerships and investment. "Indeed, we believe that if you want to make a good investment in the midst of what is still a very difficult global economy, go to Africa," she told a Senegalese audience last Wednesday. (...) Clinton's comments in Senegal that America would stand up for democracy in its pursuit of economic interests were interpreted as a swipe at China. (1)

This article starts with a brief information on the new US strategy toward sub-Saharan Africa, adopted two months earlier. The author summarizes that the new US approach is shifting focus from development aid and "idealistic development goals" to facilitating trade and investment. He explains this new approach as a reaction to growing China's influence on the continent.

6 Whole text of the MNG editorial policy is available at http://www.nation.co.ke/meta/1194-1199444157ja8l/index.html. 
Words by Hillary Clinton confirms that trade and investment cooperation started to gain attraction among US policymakers, while not putting the governance agenda completely aside. In fact, both democratic governance and economic growth were defined as pillars of the US strategy toward Africa; thus supposedly, they were seen as not mutually exclusive goals.

In August 2014, Obama organized the first US-Africa Leaders Summit, an antipode to a Forum on China-Africa Cooperation (FOCAC), which is organized by China every three years since 2000. The main focus of the summit was on economic and security cooperation. Obama invited leaders from fifty African countries, including some of the strongmen, thus effectively leaving the issues of governance aside. ${ }^{7}$ The summit was extensively covered in the Kenyan press, and quotations from Barack Obama and Secretary of State John Kerry confirmed the primary focus on economic issues.

The real reason for the entire three-day production had been an open secret even before it began. "I want the United States competing in these fast-growing markets, too," President Obama wrote in an op-ed. "I want a growing Africa buying more goods stamped 'Made in America."'(2)

On Monday, the US Secretary of State, Mr John Kerry, was straightforward about Washington's aims. "I say unabashedly: We want and we will work hard to get more American companies to invest in Africa. We also want more African companies to invest here in the United States, and there's no reason that they shouldn't," Mr Kerry said. On Friday, President Obama had told a news conference: "We want to do business with these folks."(3)

Although the summit seemed to start a new period in US-Africa relations prioritizing the economic agenda over the political issues, this would be a false picture. Obama still stressed all four pillars of his African strategy, which he illustrated during his visit to Kenya.

"We stand united in the fight against terrorism and we will be channelling more money towards this," [Obama] said. (...) The pledge to increase funding against the terrorist group was one of a series of promises that the US leader made to Kenyans as his visit came to a climax yesterday. Standing on a stump at State House in the land of his father, President Obama said that his government would support reforms in key institutions of government. (...) The development would see more direct foreign investments to Kenya (...). The US government would also pump in more money through the Power Africa Project. (...) Mr Obama reiterated the commitment of his country to help Mr Kenyatta deal with corruption in

7 Obama did not invite only four African leaders with the worst international reputation: Robert Mugabe (Zimbabwe), Omar al-Bashir (Sudan), Isaias Afwerki (Eritrea), and the representative of the transitional regime in Central African Republic following the coup d'état in 2013. 

and Their Image in the Kenyan News Discourse

government, offering technical support towards the same. (...) But Mr Obama also urged Mr Kenyatta to nurture press freedom, pointing out that it was crucial in enhancing democracy. (...) Beneath the show of solidarity, he also signalled that the war on corruption must not only be fought but seen to be won. (4)

This is a clear confirmation that Obama wanted to pursue his four-pillar African strategy in full, meaning that he saw democracy, economic growth, security and development as interconnected, mutually reinforcing and inseparable aspects of African future.

The same picture is present in comments written by the US Ambassador to Kenya Robert Godec. In 2013, he stressed both economic and political agenda as constituent parts of the US-Kenya relationship.

The United States has been Kenya's partner over the past 50 years. (...) In all of the work we do, our goal is simple: Help Kenyans make a better life. (...) Our ties are a complex web of political, economic and cultural connections that grow stronger by the day. (...) Our friendship rests on the strongest foundation, our shared belief in freedom and democracy. (5)

In August 2014, he described the US-Africa summit as a new model of partnership of equals and stressed that the US and Kenya share a lot of values, both economic and political ones.

Kenya and the US share a lot of values, share interest in growth and investment, in prosperity. (...) Are there challenges? Yes, there are still challenges, but fundamentally we want the same things. We share values on democracy, prosperity, security and we want to work together to meet these things. (...) I can tell you the level of American corporate interest in Kenya is high. They look at Kenya as a place to do business. (...) [Kenyan] government is committed to supporting and assisting investors, and we are committed to coming here and looking for opportunity. (6)

Mr. Godec further elaborated these ideas in another comment later on that year.

In recent years, Kenya has been on the move. (...) But Kenya also faces challenges, including improving security, creating jobs, and strengthening governance. (...) We have achieved much together, but there are opportunities for us to deepen our partnership. (...) Looking ahead, three areas of cooperation will be particularly important: security, trade and investment, and governing for the future. (7)

He spoke in a similar way also during the Obama's visit to Kenya.

President Obama will meet with his host, President Uhuru Kenyatta tomorrow, to discuss "issues of mutual interest," according to Mr Godec. They will range from "priority areas" such as trade and linkages, security and violent extremism in Kenya and across the region, partnerships in health, combating poaching and 
wildlife and "accelerating efforts to bolster transparency and tackle corruption." (...) Mr Godec said that his government will still press for more democratic space and fight against corruption. "The United States continues to believe that justice, human rights and rule of law are critically important. These are values that we frankly promote and work for across the world ... I am confident that we will continue to speak on those matters when and where appropriate." According to an itinerary released yesterday, Mr Obama "plans to meet with a wide cross-section" of civil society. Mr Godec said the meetings will underscore "our view that a strong and vibrant civil society is vital to robust democratic institutions, economic wellbeing, and promoting a sustainable economy including preserving Kenya's natural gifts." (8)

The presented excerpts show that US relations with Kenya follow the four pillars delineated in the 2012 African strategy and that these pillars are interconnected. The US narrative can be summarized in the following way: the US will cooperate with Africa so as the continent participates more actively on the global economic relations and benefits from them, but this requires that Africa improves its score on security, democracy and human rights, infrastructure and human capital, with which the US is ready to help Africa.

Robert Godec (who started his mission in January 2013) seems to be consistent in stressing economy, security and governance as three important arenas for US-Kenyan relations and prerequisites for Kenyan development. Barack Obama himself seems to be less consistent. On one side, he came to Kenya to attend the Global Entrepreneurship Summit, but his agenda was by no means limited to the economic domain. He focused also on security, development and good governance. He went so far to stress gay rights as part of democratic governance, which caused an open clash with his Kenyan hosts.

On the other side, his flagship event - the US-Africa Leaders Summit unambiguously prioritized economic agenda and Obama was not shy to take pictures with the invited African strongmen. Naturally, this weakened his calling for democratic reforms in Africa. Moreover, Obama distanced himself from the George W Bush practice of "exporting democracy" and instead aimed to present the US as a positive example of a democratic state and let African leaders to take the responsibility for positive changes in their countries (White 2010, 2, 5-6). Although this approach may be more positively received in other countries, it also means that the US has at least partly lost leverage to assert the democratic agenda. These two aspects have important consequences for the persuasiveness of the US narrative and its acceptance. 


\section{Reception by Kenyan Leaders}

President Kenyatta and his office are quoted on economic relations with the US only occasionally, particularly during top-level events such as US-Africa Leaders Summit.

A statement from the Presidential Strategic Communication Unit (PCSU) said Mr Kenyatta's visit would focus on strengthening ties between the US and Kenya in trade, capital investment, infrastructure, energy and security. (...) The President's spokesman, Mr Manoah Esipisu, said the US trip, the first in President Kenyatta's first term as Head of state, was purely business-related. (...) Yesterday, Mr Esipisu said the president's entourage of cabinet secretaries would be tasked with speaking to business people in the USA to secure trade and investments, as well as seek deeper cooperation in security and infrastructure development. (9)

Only few weeks later during his second tour to the US, Kenyatta stated that:

"We are keen to see the two countries exchange direct flights and I have personally raised the issue with top US offcials, latest being in a meeting with John Kerry yesterday," said President Kenyatta. (...) "The government is working hard to create a conducive business environment and I urge American investors to take advantage of this[.]" (10)

During Obama's visit to Kenya, Kenyatta stated that:

"The United States of America, from the time of our independence, has been a very strong partner and ally. Kenya has benefited from Agoa, it has benefited heavily in the health sector and education. This has been for all the years and that has never stopped. It has been on-going. The key point is (...) that Kenya as a country is not looking East or West," said President Kenyatta. (11)

The last remark clearly points out to the fact that the main interest of the Kenyan government is to sustain high economic growth. To fulfil this goal, Kenya is open to partner with any country regardless of its ideology, having the only aim to assure the necessary resources to finance the country's development, particularly the large infrastructure projects. It is a "purely business issue". What is interesting is that Kenyan leaders are willing to accept the nexus between economic and security issues, while they reject the nexus between economic and political issues. Article 4 focuses primarily on Barack Obama's speech and his "bag of goodies", while mentioning Uhuru Kenyatta only marginally.

His host President Uhuru Kenyatta said that fighting terrorism was a challenge to his government and asked for American support. (...) President Obama and his host did not, however, agree on all subjects with discussion about gay rights being the point of departure. Mr Kenyatta insisted that the subject was inconsistent with 
the African culture and it was thus imprudent to force it on Kenyans. He also reiterated that the subject was not on top of Kenyans minds at the moment. (...) Speaking after their bilateral meetings, the two presidents expressed confidence in the direction the Kenya-US partnership was headed. (4)

For the reporter, Kenyatta's reaction on economic cooperation was not important, which a reader can read as a confirmation of shared economic interests between the two countries. In the security domain, the reporter extensively covers what Obama said about anti-terrorist collaboration, followed by Kenyatta's demand to further deepen it (which Obama indeed promised). On the other side, in the political domain, Kenyatta emphasized the differences between American and African cultures as a justification for the rejection of the Obama's call for the need to improve the human rights record. Although gay rights are rather a marginal issue, it was highlighted in the article as "the point of departure" between the two presidents. This indicates that the reception of the US narrative among the Kenyan elites (as represented by the President) is different from its initial meaning.

This is clearly confirmed in the opinion article written by the president's speechwriter.

Obama came to Kenya. A couple of days later, he left. Those imperfect sentences are the brackets which enclose one of the more momentous chapters of this country's great adventure. (...) Had Obama come here in the 1990s or early this century, the agenda would have included human rights, greater political freedom, release of political prisoners, free assembly, even electoral playing field, liberalisation of the economy and presidential term limits. But last week we spoke about shared values, entrepreneurship, the rise of a new Africa, a wide spectrum of partnership opportunities and investment. In other words, the USA was not "talking baby" to a petulant infant; it was having a rational conversation with a mature and responsible grown up. (...) It was not always this way. And it is getting better every day. I am speaking about Kenya's capacity to testify the entrepreneurship, innovation, investment and growth on a transformative scale. (12)

This text is quite straightforward in contrasting economic agenda with the political one. The former is seen as "a rational conversation" between equal partners who share the interest in economic opportunities and investment. Thus, the latter seems to be viewed as an irrational conversation between a teacher and his seemingly disobedient pupil. Human rights and good governance are seen as relicts of the past. This is surprising as Obama during his visit spoke also about corruption, press freedom, accountability of leaders, democracy and even gay rights, thus going even further than George Bush and Bill Clinton in the 1990s. However, this part of Obama's address to 
Kenyans seems to be neglected or at least seen as inferior to economic and security issues.

This is confirmed by an analysis of winners and losers of the Obama's visit (13). According to the author, the biggest winner is President Kenyatta, whose standing has boosted, thanks to the visit. Other winners are cabinet secretaries for foreign affairs and international trade, industrialization and enterprise development and interior. Finally, youth and women entrepreneurs are seen also as winners. On the other side, main losers are opposition leaders ("their calls for US pressure on the Jubilee government were rejected") and mainstream civil society (which "was not accorded much time, space and recognition"). The reporter's observation thus confirms that Obama's visit prioritized economic and security agenda over the issues of democracy and human rights. This means that in Nairobi, Obama himself undermined the US narrative and weakened the connection between economic, security, political and development issues.

If the constituent parts of the narrative are not in reality so closely interconnected as proclaimed, then it creates an opportunity for the receiving audience to take these parts as more or less separate narratives. This is exactly what Kenyan leaders do. They transform the US narrative and forward the message to the citizens in the following way: the US is a valuable partner for Kenyan development due to its investment into infrastructure, cooperation in the security sphere and financial support for the development initiatives.

\section{Reception by Kenyan Society}

Opinion articles and letters written by representatives of the civil society such as journalists -columnists, university scholars, lawyers and readers show a wider spectrum of how the US narrative is received.

First position follows the US narrative and recognizes that the relationship between the two countries has a political, economic and security dimension. Kenyans are said to support democratic values and cooperate with the US to bolster these values in the region.

The independence Constitution survived a near half-century because it captured the aspirations of Kenyans: equality under law, freedom of speech, the right to private property, and tolerance of different faiths. We share these values with the Americans and where it matters, like in the Horn of Africa, Kenyans and Americans have stood together to defend these values. (...) Partnerships such as these guarantee stability, bring about prosperity, bolster values, and protect and preserve security. (14) 
Authors representing this position, such as a reader from Thika, express their disappointment that the US focuses on economic opportunities and overlook the nature of African regimes.

Last week's US-Africa leaders summit was initially received with bated breath. Unfortunately the forum (...) was heavily skewed towards US economic interests. Apart from rekindling diplomatic relations between US and Africa, the Obama administration failed to address key problems bedevilling the continent such as poor governance, corruption, insecurity, civil wars, and political and economic turmoil. (15)

The second position follows the narrative of Kenyan leaders. "Soft" version of this position highlights results of the economic cooperation between the two countries and remains silent on political questions.

Whoever is elected President [of the US], the next Administration must radically change the approach to engaging Africa. (...) Key to this engagement is the realisation that Africa offers numerous profitable opportunities for Americans that would also benefit Africa through economic growth and job creation. (...) Rather than complaining about the imperfections of the Africa-China relations, the US must rethink its African strategy carefully, or else it will soon be a marginal player in the continent. (16)

Contrarily, the "hard" version of this position rejects that political questions are an important issue in US-Kenyan relations. One author sees such questions as inadequate and not solving the immediate and urgent problems of the country. Another author sees the US emphasis on democracy as a moralistic hypocrisy stemming from the post-Cold War hegemony. Two authors vilify the US approach as opportunistic and caused by the growing Chinese engagement in Africa.

It is, however, improper to divert the attention (...) from the main agenda. The summit seeks to promote innovation, enhance market for products and explore funding for small scale traders. (...) I am aware that all these discussion will take place without regard to sexual orientation. (...) It is, therefore, distracting to preoccupy ourselves with the debate on sexual orientation at the expense of more relevant themes[.] (...) The debate on sexual orientation can wait. (17)

The African leaders would no doubt have sought assurances that the forum would not be used to lecture them on such "alien" impositions as human rights, freedom of speech, good governance, democracy (...). Gone is the imperialistic finger-wagging and moralistic lecturing, to be replaced by more pragmatic relationships built on the need to secure US commercial and political influence before China runs away with the continent. That's the only reason I can think of the massive wooing of 


\section{Vilém Řehák, US-Kenya Economic Relations under Obama and Their Image in the Kenyan News Discourse}

Africa in a style that says the US will put its commercial and strategic interests above all the self-righteous hypocrisy that has informed relationships over the past two decades. (18)

In the past such gatherings would be dominated by such issues as human rights - galore abuses in Africa - democracy, governance, and US aid. This time the emphasis was on how the US and African governments can assist, by formulating policies, business people and entities on both sides make money on an "all-win" basis. (...) [T]he China's mantra on investment in Africa, "No questions asked," was in vogue. (19)

What has changed in my opinion is that US interests in Africa are under threat. When US interests are threatened, she becomes paranoid. She can do the unthinkable. Her interests supersede truth, democracy, rule of law and human rights; US interests come first. (20)

The third position lies somewhere between. It does not reject the US narrative as such, but it observes that it is the US itself that does not behave in accord with this narrative. US actions suggest that economic and security parts of the narrative are more important than political and development parts. "Soft" version of this position recognizes that the US still speaks about democracy and human rights in Africa, but that the tone has shifted from the criticizing one to the advising one.

The US president did deliver some very strong admonitions on pressing matters such as corruption, human rights, good governance and equal allocation of resources, but he did so carefully, in terms designed not to annoy his host. He took on the tone of offering friendly advice rather than criticising the Kenyatta administration and, as often as he could, praised the government for the corrective steps it was taking. (21)

As a result, even in case of disagreements on certain issues, the general trend of close and deepening cooperation cannot be disrupted or reversed.

The second moment was the much-anticipated disagreement on gay rights. Each president stated his case clearly; neither conceded ground; and yet, there was no fight. They ended that press conference arm-in-arm. Kenyans, used to name-calling and insult-hurling, were shown a different way of differing: the gentleman's disagreement. (22)

The "middle" version recognizes that the US still wishes to pursue democratic agenda in Africa, but that it changed (or had to change) means of how to achieve this goal. Instead of exerting top-down pressure on African leaders (political approach), the US has decided to support young innovative entrepreneurs to bring change from below (economic approach). This means 
that the US is less speaking about democracy in Africa while not forsaking the goal to foster it.

America has not given up on dreaming of a democratic and prosperous Africa where citizens are respected and rights protected. The Washington summit, however, represents a subtle but important shift in focus and tactics of engagement. (...). [T]he US is showing the kind of pragmatism we have come to expect from - you guessed it - China! This is not to say that the US is adopting China's see-noevil, hear-no-evil approach. (...) America is changing the way it relates to Africa. It is a subtle shift away from preaching politics and democracy to its leaders, to inspiring its youth and its entrepreneurs to drive the change. (23)

The "hard" version asserts that the US still wishes to pursue democratic agenda in Africa, but only if it does not clash with other strategic interests on the continent.

President Obama wishes to give deals to "well governed" states in order to reward them and encourage other investors to follow suit. The problem with this is that, with the exception of South Africa, the biggest players on the continent - whether we are talking in political or economic terms - are not full democracies. (...) This reflects a broader trend in which the American government has been willing to compromise on governance issues where its security is at stake. (24)

Finally, there is also the fourth position, which represents fundamentally a different narrative. It denies not only the political issues but also the economic cooperation. Although the renewed US economic interest on Africa has the potential to foster African development by increased trade flows and investment, it is primarily a response to growing Chinese engagement on the continent. The US follows its own strategic interests, regardless of whether it they match with African interests and needs. According to different authors, Africa has never been a priority for the US, and Barack Obama has not changed that. His interest in Africa did not go beyond shallow symbolism, which is best represented by the US-Africa Leaders Summit. ${ }^{8}$ The summit brought no real results, just promised of future investment.

African heads of state were summoned to Washington for a photo opportunity with President Obama and his Wife to further American interests. For some, the real audience for that performance of international relations was China. The message? America can bring any African head of state to Washington because it is still the major global power and a country that African states want to do business with. (25)

8 The summit was a very late reaction to similar events organized regularly by Japan (since 1993), China (since 2000) and India (since 2008). The US has organized AGOA Forum since 2001, but it is attended mostly by trade and finance ministers, not heads of state. 


\section{Vilém Řehák, US-Kenya Economic Relations under Obama}

and Their Image in the Kenyan News Discourse

President Obama summoned African leaders to Washington to remind them who's still boss - Uncle Sam, not any latter-day Chairman Mao. It is classic American hubris, that. (2)

Veni, Vidi, Vici? All of the 50-odd African leaders who travelled to the United States can say with satisfaction they went and they saw, but how many can claim they conquered? (26)

Obama has failed to outgrow the defining symbolism of being the first AfricanAmerican to be elected president in America. (...) Obama knows a lot about Africa. That he chose to ground his main speech in Senegal on the need for African states to expand the rights of gay people shows his obsession with shallow symbolism. Obama should know that Africans are addressing more important and pressing challenges like the right to food, education, affordable health care, access to drinking water, etc. The point he was really intent on making on gay rights is that America will deal with Africans on its terms and on issues as it defines. Obama is loved and adored in Kenya and in Africa. (...) But don't expect a lot. There is no substance in his great speeches. He is the head of an empire in its twilight facing many challenges. Africa is not a priority and has never been one. (27)

And then he [Obama] was gone. And a thoughtful Kenyan must ask: so what? (...) Certainly, we reaped some significant benefits. (...) And yet, the cynics are out in force, asking whether the US delivered any real "goodies" or whether Kenya is any different after its most powerful relative left. (...) What did we actually expect Barack Obama to do for us? Can he solve our problems, accelerate our development, dole out largesse? Why do we remain so stunted, that we expect miracles from what was just a visit, a conference, a set of talks? It was a good visit, and some good things happened. That is all. (28)

\section{Conclusion}

Obama's election was supposed to be a turning point in the US foreign policy (White 2010, 1). He promised to change the outdated dogmas and renew idealism into the foreign policy (Unger 2016, 1-2). Although Africa was barely mentioned during the election campaign, Obama showed more interest and knowledge than his predecessors. In his public statements, he focused on good governance and democracy as key topics (Mezzell 2010, 88). Strengthening democratic institutions was mentioned as the first of four pillars of the US strategy toward Sub-Saharan Africa. This new strategy and the first US Africa Summit indicated that the Obama administration was giving more attention to the continent (Rye Olsen 2017, 73).

However, Obama's Africa policy was ambiguous as he coupled the cultivation of liberal democratic values with long-term national security interests 
(Dumbuya 2015, 9). In some Countries such as Senegal, Liberia or Malawi, his administration pressed for democratic reforms and anti-corruption measures. In some countries such as Rwanda, Uganda or Ethiopia, he prioritized stability and aligned with authoritarian leaders (Unger 2016, 13). In some countries such as Angola, Nigeria and Gabon, he focused on securing oil supplies and trade promotion, regardless of the authoritarian nature of their regimes. In this respect, Obama was a result-driven pragmatist (Holland 2016, 9), not much different from his predecessors.

Kenya seems to be somewhere between the first group and second group. Maina $(2005,65)$ identified three historical periods in the US policy toward Kenya, reflecting the US domestic priorities: containment of the Soviet influence, promotion of democracy and the war on terrorism. Since the independence, mutual relations have been convergent on security and economic cooperation and divergent on governance issues (Munyi 2018, 50). Obama did not change this. He continued with the anti-terrorist cooperation and experimented with the promotion of democracy and fight against corruption, but his main legacy is the Power Africa Initiative and huge amount of investment into Kenya's energy sector. Although he wished to focus his Africa policy on governance, his contribution was pragmatic and traditional - trade, investment and security. There is always a difference between the rhetorical vision of a presidential candidate and the dictates of the presidential office (Munyi 2018, 49-50).

This ambiguity is reflected in the local news discourse. The US wished to disseminate a narrative that economy, security, good governance and human resources are four interconnected, inseparable and mutually reinforcing parts of African development. If Kenya wishes to achieve its goal to become middleincome country by 2030, it must make progress in all these four pillars, with the help from the US. However, concrete actions of the US foreign policy in Africa were contradictory to this narrative. Although the US followed all these four pillars, some of them seemed to be more important than others.

Any narrative is rarely heard as intended. It is always interpreted by audiences in the context of their own experience (Nye 2004, 111; Miskimmon et al. $2013,169)$. If the narrative is incoherent or if it does not match with actions, it is weak, less persuasive and more likely to be rejected or modified. Kenyan leaders seem to internalize the economic part of the narrative and accept the economic/security nexus, but they reject the economic/political nexus. They transform the narrative to highlight economic and security benefits from the cooperation with the US - the "Obama bonus". Those issues where the US and Kenyan views differ are concealed. 
Finally, people of Kenya may receive these narratives in several different ways. This article has identified four basic positions in the local news discourse. Some authors agree with the US narrative, although this is rather an exception. Some authors agree with the narrative as transformed by Kenyan leaders, which means that they reject an important part of the original narrative. Some authors stand somewhere between: they also tend to highlight the economic benefits, but they do not reject the US narrative. However, they recognize that the US behaves differently from their narrative: they try to find out reasons for this ambiguity and they doubt about the real intents of the US policy in Africa.

Some authors reject the whole narrative, including its economic part. There was no Obama bonus in 2008 nor in 2015 (article 28). Most of comments focus on two top-level events: the US-Africa Leaders Summit in Washington and Obama's visit to Kenya. Both events were highly symbolic and, according to this group of authors, served two main goals: to promote US economic interests in Africa and to counterbalance the growing Chinese influence on the continent. In reality, Africa has never been a priority for the US. Obama has fallen short of achieving any transformation of the US foreign policy in general and the Africa policy in particular (Unger 2016, 3; Rye Olsen 2017, 74).

The present analysis shows that the image of US-Kenya economic relations in the local news discourse is not uniform and at least three different and clashing narratives can be identified. Although the US narrative and the narrative of Kenyan leaders partly overlap, there is a crucial difference between them. Moreover, while some participants of the news discourse internalize (to a different degree) these narratives, there is also a third narrative, which presents US-Kenya economic relations in a different perspective.

\section{References}

\section{Primary Sources}

1, Mumo, Muthoki. US raises stakes in Africa to cut back China's trade influence. The Daily Nation, $5^{\text {th }}$ August 2012.

2, Madowo, Larry. US-Africa summit was more about style than substance. The Daily Nation, $12^{\text {th }}$ August 2014.

3, Muriithi, BMJ. US political, business leaders woo Africa at investment talks. The Daily Nation, 6 ${ }^{\text {th }}$ August 2014.

4, Wanga, Justus. Obama's bag of goodies for Kenya. The Daily Nation, $26^{\text {th }}$ July 2015. 


\section{Journal of Nationalism, Memory \& Language Politics 12(1)}

5, Godec, Robert. For half a century, America has been here as Kenya's partner and friend. The Daily Nation, $8^{\text {th }}$ December 2013.

6, Teyie, Andrew. Envoy: America is with Kenya; we are with the President (interview with Robert Godec). The Daily Nation, $17^{\text {th }}$ August 2014.

7, Godec, Robert. America and Kenya will benefit from this new model of partnership of equals. The Daily Nation, $10^{\text {th }}$ December 2014.

8, Mutambo, Aggrey and Stella Cherono. Kenya ready to receive US leader and sign key business deals during summit. The Daily Nation, $24^{\text {th }}$ July 2015.

9, Njagi, John. Trade tops Uhuru's agenda in the US. The Daily Nation, $4^{\text {th }}$ August 2014.

10, Limo, Edwin. Uhuru pushes for direct US flights. The Daily Nation, $29^{\text {th }}$ September 2014.

11, Ochieng, Lilian and Joshua Masinde. Sh100 billion investment pledge as global meeting closes doors. The Daily Nation, 27 $7^{\text {th }}$ July 2015.

12, Ng'eno, Eric. If Kenya is not rising, you're looking in wrong direction. The Daily Nation, $2^{\text {nd }}$ August 2015.

13, Teyie, Andrew. Sh1.2 trillion deal struck but not all are winners after Obama's visit. The Daily Nation, $2^{\text {nd }}$ August 2015.

14, Obonyo, Levi. Kenya-US relations a cycle of friendship. The Daily Nation, $27^{\text {th }}$ May 2015.

15, Muthama, Joseph. US-Africa summit was much fanfare and no substance. The Daily Nation, $13^{\text {th }}$ August 2014.

16, Kimenyi, Mwangi. America will have to craft new terms of engagement with African countries. The Daily Nation, $11^{\text {th }}$ October 2012.

17, Wambiya, Auscar. Obama visit is all about trade and innovation, not gay debate. The Daily Nation, $25^{\text {th }}$ July 2015.

18, Gaitho, Macharia. By gathering African leaders to his country, Obama has pulled off a coup. The Daily Nation, $5^{\text {th }}$ August 2014.

19, Mbitiru, Chege. US capital feels the pinch as African leaders visit. The Daily Nation, $11^{\text {th }}$ August 2014.

20, Ambuka, Jacktone. American interests solely behind change of heart towards Kenya. The Daily Nation, $8^{\text {th }}$ August 2014.

21, Gaitho, Macharia. US leader's visit massive boost for Kenya. The Daily Nation, $28^{\text {th }}$ July 2015.

22, Bindra, Sunny. Three observations from Obama's historic visit. The Daily Nation, $2^{\text {nd }}$ August 2015.

23, Kalinaki, Daniel. From tyrants to turbines: Obama's subtle shift in African foreign policy. The Daily Nation, $10^{\text {th }}$ August 2014.

24, Cheeseman, Nic. What Obama's Washington Summit means for Uhuru and other African leaders. The Daily Nation, $3^{\text {rd }}$ August 2014.

25, Lynch, Gabrielle. Who benefited from US-Africa summit? The Daily Nation, $30^{\text {th }}$ August 2014.

26, Gaitho, Macharia. Uhuru brought cowboy boots and a stetson from America, if nothing else. The Daily Nation, $12^{\text {th }}$ August 2014. 


\section{Vilém Řehák, US-Kenya Economic Relations under Obama and Their Image in the Kenyan News Discourse}

27, Abdullahi, Ahmednasir. Africa has never been a priority for the United States. The Daily Nation, 30 June 2013.

28, Bindra, Sunny. The US President came to Kenya. So what? The Daily Nation, $9^{\text {th }}$ August 2015.

\section{Secondary Sources}

Agyeman-Duah, Ivor. 2015. "Race and the Great Expectations." In Assessing Barack Obama's Africa Policy. Suggestions for Him and African Leaders, edited by Abdul Karim Bangura, 2740. Lanham: University Press of America.

Banjo, Adewale. 2010. "U.S. Development Diplomacy in Africa: From Bill Clinton to George W. Bush." African Journal of Political Science and International Relations 4 (4): 140-149.

Cheeseman, Nic. 2014. "Are newspapers on their way out?" The Sunday Nation. Accessed February 24, 2018. https://www.nation.co.ke/oped/opinion/Media-Newspapers-Kenya-DailyNation/440808-2262878-1qk61u/index.html.

Dijk, Teun van. 1988. News as Discourse. Hillsdale: Lawrence Erlbaum Associates.

Dumbuya, Peter A. 2015. "Continuity or Change in US Relations with Africa during the Obama Presidency.” In Assessing Barack Obama’s Africa Policy. Suggestions for Him and African Leaders, edited by Abdul Karim Bangura, 1-26. Lanham: University Press of America.

Freedom House. 2016. Freedom of the Press 2016, Country Report on Kenya. Accessed February 24, 2018. https://freedomhouse.org/report/freedom-press/2016/kenya.

GeoPoll. 2015. Data on Newspaper, Magazine Readership in Kenya. Accessed February 24, 2018. http://blog.geopoll.com/data-on-newspaper-magazine-readership-in-kenya.

Hesse, Brian J. 2005. "Celebrate or Hold Suspect? Bill Clinton and George W. Bush in Africa." Journal of Contemporary African Studies 23 (3): 327-344.

Holland, Jack. 2016. “Obama as Modern Jeffersonian." In The Obama Doctrine: A Legacy of Continuity in US Foreign Policy?, edited by Michelle Bentley, and Jack Holland, 40-53. New York: Routledge. Quotations in the presented text are from an author produced version. Accessed February 24, 2018. http://eprints.whiterose.ac.uk/95843/.

Ilo, Saidat. 2015. "Economic Aid.” In Assessing Barack Obama's Africa Policy. Suggestions for Him and African Leaders, edited by Abdul Karim Bangura, 281-294. Lanham: University Press of America.

Joselow, Gabe. 2013. "US Official Says Kenya's Elections Have ,Consequences." Voice of America. Accessed February 24, 2018. https://www.voanews.com/a/us-official-says-kenyaelections-have-consequences/1599063.html.

Lawson, Letitia. 2007. "U.S. Africa Policy since the Cold War." Strategic Insights 6 (1): 1-14. Accessed February 24, 2018. https://calhoun.nps.edu/bitstream/handle/10945/11266/lawsonJan07.pdf?sequence $=1$.

Mabera, Faith. 2016. "Kenya's Foreign Policy in Context (1963-2015)." South African Journal of International Affairs 23 (3): 365-384.

Machar, Benjamin Aciek. 2015. "Kenyan Politics." In Assessing Barack Obama's Africa Policy. Suggestions for Him and African Leaders, edited by Abdul Karim Bangura, 189-221. Lanham: University Press of America. 
Maina, Priscilla Wangui. 2005. Terrorism, Democratisation, and American Foreign Policy towards Kenya: 1990 - Present. Unpublished MA Thesis, University of the Witwatersrand Johannesburg, Faculty of Humanities and Social Sciences. Accessed February 24, 2018. http://wiredspace.wits.ac.za/handle/10539/1780.

Mathenge, Oliver, Samuel Siringi, and David Mugony. 2008. "Obama bonus is coming to Kenya." The Daily Nation. Accessed February 24, 2018. https://www.nation.co.ke/ news/1056-488472-kn656rz/index.html.

Mezzell, Ann. 2010. "US Policy Shifts on Sub-Saharan Africa. An Assessment of Contending Predictions." Air and Space Power Journal - Africa and Francophonie 1 (4): 79-96. Accessed February 24, 2018. http://www.airuniversity.af.mil/Portals/10/ASPJ_French/journals_E/ Volume-01_Issue-4/mezzell_e.pdf.

Miskimmon, Alister, Ben O'Loughlin, and Laura Roselle. 2012. Forging the World: Strategic Narratives and International Relations. London: Royal Holloway University. Accessed February 24, 2018. http://static1.1.sqspcdn.com/static/f/127762/16079410/1326798495050/ Forging+the+World+Working+Paper+2012.pdf?token=FzIoX39eqIRlx80uLHEZl3ZTcRo $\% 3 \mathrm{D}$.

Miskimmon, Alister, Ben O'Loughlin, and Laura Roselle. 2013. Strategic Narratives. Communication Power and the New World Order. New York: Routledge.

Moegi, Bosire R. 1993. Kenya - U.S. Relations: An Interplay Of National Interest, 1963 - 1991. Unpublished MA Thesis, University of Nairobi, Department Of Government. Accessed February 24, 2018. http://erepository.uonbi.ac.ke/bitstream/handle/11295/19382/Moegi_Kenya\%20-\%20U.S.\%20Relations\%20\%20An\%20Interplay\%20Of\%20National\%20 Interest $\% 20 \% 2 c \% 201963 \% 20-\% 201991$.pdf? sequence=3\&isAllowed=y.

Munyi, Elijah Nyaga. 2018. "Obama Delivers for Kenya: On Business.” In The World Views of the Obama Era: From Hope to Disillusionment, edited by Matthias Maass, 49-64. Cham: Palgrave Macmillan.

Nyabuga, George, and Nancy Booker. 2013. Mapping Digital Media: Kenya. London: The Open Society Foundations. Accessed February 24, 2018. https://www.opensocietyfoundations.org/sites/default/files/mapping-digital-media-kenya-20130321.pdf.

Nye, Joseph S. Jr. 2004. Soft Power. The Means to Success in World Politics. New York: Public Affairs.

Obala, Luke. 2014. The Myths and Realities of Kenya's turning to the East. Doha: Al Jazeera Center for Studies. Accessed February 24, 2018. http://studies.aljazeera.net/mritems/Docu ments/2014/5/22/201452212924830734Kenya\%20and\%20China.pdf.

Obama, Barack. 2009. “The Ghana Speech.” Huffington Post. Accessed February 24, 2018. https://www.huffingtonpost.com/2009/07/11/obama-ghana-speech-full-t_n_230009. html.

Pflanz, Mike. 2013. "British Envoy to Attend Uhuru Kenyatta's Inauguration.” The Telegraph. Accessed February 24, 2018. http://www.telegraph.co.uk/news/worldnews/africaandindianocean/kenya/9971734/British-envoy-to-attend-Uhuru-Kenyattas-inauguration.html.

Phillips, Nelson, and Cynthia Hardy. 2002. Discourse Analysis. Investigating Processes of Social Construction. SAGE University Papers Series on Qualitative Research Methods, vol. 50. SAGE: Thousand Oaks. 


\section{Vilém Řehák, US-Kenya Economic Relations under Obama and Their Image in the Kenyan News Discourse}

Rambaud, Brice. 2008. "Caught between Information and Condemnation. The Kenyan Media in the Electoral Campaigns of December 2007." In: Les Cahiers d'Afrique de l'Est $N^{\circ} 38$ : The General Elections in Kenya, 2007, edited by Jérôme Lafargue, 57-107. Nairobi: Institut Français de Recherche en Afrique. Accessed February 24, 2018. http://ifra-nairobi.net/wpcontent/uploads/2017/07/Cahier_38.pdf.

Reporters without Borders. 2017. 2017 World Press Freedom Index. Accessed February 24, 2018. https://rsf.org/en/ranking.

Rothmyer, Karen. 2010. "A Passion for Print: Why Newspapers are Thriving in Kenya." Columbia Journalism Review online. Accessed February 24, 2018. http://www.cjr.org/ feature/a_passion_for_print.php.

Rye Olsen, Gorm. 2017. “Obama and US Policy towards Africa: A Study in Failure?” International Politics 54 (1): 73-88.

Unger, David. 2016. "The Foreign Policy Legacy of Barack Obama.” The International Spectator 51 (4): 1-16. Accessed February 24, 2018. http://www.iai.it/sites/default/files/unger.pdf.

Waters, Robert Anthony. 2009. Historical Dictionary of United States-Africa Relations. Lanham: Scarecrow Press.

Weldes, Jutta. 2006. "High Politics and Low Data." In Interpretation and Method. Empirical Research Methods and the Interpretive Turn, edited by Dvora Yanow, and Peregrine Schwartz-Shea, 176-186. Armonk: M. E. Sharpe.

White, Laura. 2010. What Kind of Change for Africa? U.S. Policy in Africa under the Obama Administration. Paris: Institut des Relations Internationales et Strategiques. Accessed February 24, 2018. http://www.iris-france.org/docs/kfm_docs/docs/2010-04-obama-africa. pdf.

White House. 2012. U.S. Strategy toward Sub-Saharan Africa. Washington: The White House. Accessed February 24, 2018. https://2009-2017.state.gov/documents/organization/209377.pdf.

Wodak, Ruth. 1996. “The Genesis of Racist Discourse in Austria since 1989.” In Readings in Critical Discourse Analysis. Texts and Practices, edited by Carmen Rosa Caldas-Coulthard, and Malcolm Coulthard, 107-128. London: Routledge. 